\title{
PEMANFAATAN ASPEK KEBAHASAAN BENTUK KATA TUTURAN HUMOR DALAM KARIKATUR
}

\author{
Gita Anggria Resticka \\ Universitas Jenderal Soedirman \\ gitaanggriaresticka@gmail.com; gitaunsoed@gmail.com
}

\begin{abstract}
The use of language in society is determined by linguistic and social factors. This also applies to caricature. The caricatures are displayed with a variety of funny and interesting images, and followed by a short sentence. The use of language is typical in caricature makes it as a register in linguistic that is interesting to be analyzed. The messageof caricature in each picturecan be assessed with pragmatics approach. Wijana (2004) says that caricature intentionally createsutterances, which distort the pragmatic principles and parameters, either directly or through irrational figure or figures of participants in speech act. This study belongs to a descriptive qualitative research emphasizing on the process and meaning of speech acts.In a caricature, to reveal the message of humor, different types of speech acts, pragmatic function, conversational implicatures and categories contained in various types of utterances in the caricature discourse should be investigated.
\end{abstract}

Keywords: humor speech, caricature, pragmatics

\begin{abstract}
ABSTRAK
Pemakaian bahasa dalam masyarakat ditentukan oleh faktor linguistik dan sosial. Hal ini juga berlaku pada karikatur. Karikatur tersebut ditampilkan dengan berbagai gambar yang lucu dan menarik serta diikuti kalimat singkat. Penggunaan bahasa yang khas dalam karikatur menjadikan karikatur sebagai suatu register dalam kebahasaan yang menarik untuk diteliti. Untuk mengetahui maksud karikatur dalam tiap gambar, hal ini dapat dikaji secara pragmatik. Wijana (2004) mengatakan bahwa karikatur secara sengaja menciptakan tuturan yang menyimpangkan prinsip-prinsip dan parameter pragmatik secara langsung atau lewat perantara tokoh atau tokoh-tokoh rekaannya yang berperan sebagai peserta tindak tutur yang irrasional. Penelitian ini merupakan jenis penelitian kualitatif deskriptif dengan menekankan pada masalah proses dan makna (tindak tutur). Dalam sebuah karikatur, untuk sampai pada pemahaman humor yang sebenarnya, hal yang perlu dilacak adalah berbagai jenis tindak tutur, fungsi pragmatis, implikatur percakapan dan kategorinya yang dikandung oleh berbagai jenis tuturan dalam wacana karikatur tersebut.
\end{abstract}

Kata Kunci: tuturan humor, karikatur, pragmatik 


\section{PENGANTAR}

Piranti yang paling utama dalam upaya penyampaian maksud dan kehendak tersebut adalah dengan menggunakan bahasa. Proses komunikasi membutuhkan lebih dari seorang, satu orang sebagai penutur dan yang lain sebagai mitra tutur, dan peran ini bisa saling menggantikan. Penutur mengungkapkan gagasannya sedangkan mitra tutur menafsirkan gagasan tersebut. Komunikasi tersebut efektif jika dapat ditafsirkan sama antara penutur dan mitra tuturnya. Bahasa digunakan manusia untuk menyampaikan berbagai kepentingan politik, ekonomi, sosial, dan budaya. Selain itu, manusia juga dapat menyampaikan perintah, pertanyaan, permohonan, penolakan, kritik, maupun humor. Oleh karena itu, dalam berkomunikasi, seorang penutur dituntut untuk menggunakan tuturan sesuai dengan konteks agar pesan atau amanat yang hendak disampaikan dapat ditafsirkan sama oleh mitra tuturnya sehingga tercipta komunikasi yang efektif.

Pemakaian bahasa dalam masyarakat selain ditentukan oleh faktor-faktor linguistik juga ditentukan oleh faktor-faktor sosial. Hal ini juga berlaku pada karikatur. Karikatur tersebut ditampilkan dengan berbagai gambar yang lucu dan menarik serta diikuti kalimat singkat. Hal tersebut menunjukkan bahwa karikatur adalah sebuah wacana yang utuh. Analisis wacana berkaitan dengan teks, konteks, dan wacana itu sendiri. Hal tersebut penting karena karikatur dibuat berdasarkan pola pikir pengarang serta fenomena sosial, budaya, bahkan politik yang terus berkembang dalam lingkungan masyarakat. Karikatur merupakan sebuah karya seni yang didalamnya terdapat pengungkapan ide gagasan dan termasuk dalam jenis media grafis atau media visual karena hanya dapat dicerna oleh indera penglihatan saja. Prakarikatur sama dengan kartun strip, kartun kata, kartun komik, dan kartun animasi yang merupakan bagian dari kartun. Jika kartun digambarkan sebagai gambar yang lucu atau dilucukan supaya pembaca terhibur, tersenyum, atau tertawa geli, karikatur adalah bagian kartun yang diberi muatan pesan yang mempunyai nuansa kritik atau usulan terhadap seseorang atau kelompok. Meskipun cara penyajiannya disertai dengan humor, karikatur merupakan kartun satire yang terkadang tidak menghibur bahkan dapat membuat seseorang tersenyum sinis.

Di dalam masyarakat, selama ini berkembang kesalahpahaman bahwa dalam karikatur mencakup seluruh kriteria yang bersifat mengritik atau menyindir. Sebenarnya, karikatur hanyalah bagian dari kartun dengan ciri deformasi atau distorsi wajah, biasanya wajah tokoh manusia yang dijadikan sasarannya (Wijana, 1995:8). Karikatur sebagai suatu bentuk tanggapan lucu dalam citra visual dijadikan sebagai wahana kritik sosial. Sementara itu, 
tokoh-tokoh karikatur adalah tokohtokoh tiruan lewat distorsi untuk memberikan persepsi tertentu kepada pembaca sehingga sering kali disebut portrait caricature (Wijana, 1995:8). Hal ini dapat dikatakan bahwa karikatur berkaitan dengan aspek pragmatik karena penggunaan bahasa dalam karikatur merupakan suatu fungsi bahasa sebagai alat komunikasi antar manusia. Rahardi (2000:48) menyatakan bahwa pragmatik mengkaji maksud penutur dalam menuturkan satuan lingual tertentu pada sebuah bahasa. Konteks digunakan untuk mengungkapkan maksud (makna penutur) yang tersembunyi di balik sebuah ujaran/tuturan (Kridalaksana, 1983:95). Oleh karena itu, sebuah tuturan dapat digunakan untuk beberapa maksud dan begitupun juga dengan satu maksud tertentu dapat diungkapkan dengan beberapa tuturan.

Penggunaan bahasayang khas dalam karikatur menjadikan karikatur sebagai suatu register dalam kebahasaan yang menarik untuk diteliti. Maksud karikatur dalam tiap gambar dapat dikaji secara pragmatik. Pragmatik merupakan analisis linguistik yang memungkinkan mitra tutur memahami maksud dari penutur. Dengan adanya maksud yang terkandung dalam sebuah karikatur yang diutarakan dengan berbagai jenis dan macam tindak tutur, hal ini perlu dilakukan suatu analisis tentang tindak tutur, fungsi pragmatis dan implikatur sehingga maksud, misi, serta tujuan dari penciptaan karikatur dapat diketahui. Kajian pragmatik dianggap relevan untuk diterapkan dalam penelitian ini untuk melihat penggunaan tindak tutur dalam sebuah karikatur sehingga dapat bermanfaat bagi perkembangan keilmuan. Selanjutnya, alasan dikemukakannya teori implikatur dalam penelitian ini adalah kenyataan bahwa sebuah tuturan dapat mempunyai implikasi yang berupa proposisi yang sebenarnya bukan bagian tuturan tersebut dan tidak pula merupakan konsekuensi yang harus ada dari tuturan itu. Dalam kaitannya dengan karikatur, ada wacana humor yang mengandung banyak implikatur percakapan. Adanya pernyataan implikatif yang tidak merupakan bagian tuturan di dalam jenis percakapan merupakan potensi yang besar dalam penciptaan humor. Efek lucu yang mengandung keberhasilan humor dapat tercipta dengan memanfaatkan fenomena implikatur percakapan selain itu juga dapat memanfaatkan aspekaspek kebahasaan seperti fonologi, morfologi, sintaksis dan leksikon.

Penelitian ini bertujuan menemukan segi humor dalam karikatur yang terdapat di media massa dengan melihat dari pemanfaatan aspek-aspek kebahasaan dalam pengungkapan ide gagasan dan selanjutnya mengetahui jenis-jenis tindak tutur, impliktur dan daya pragmatik dalam karikatur tersebut. Penelitian ini merupakan jenis penelitian kualitatif deskriptif dengan menekankan pada masalah proses dan makna (tindak tutur). Teknik penarikan 
sampelyang digunakan dalam penelitian ini adalah sampel bertujuan (purposive sampling) yaitu sampel yang terpilih dianggap dapat mewakili informasi.

\section{TEORI DAN METODE PENELITIAN}

Penelitian ini menggunakan teori pragmatik, karena sebuah pesan atau gagasan tidak dapat dipahami tanpa mengetahui aspek pragmatiknya. Pragmatik adalah studi tentang hubungan antara bentuk-bentuk linguistik dan pemakai bentuk-bentuk itu (Yule, 2014:5). Menurut Searle, Kiefer, Bierwisch (dalam Levinson, 1984:6), salah satu dari kata yang memberikan kesan bahwa sesuatu yang spesifik dan teknis yang sering dibicarakan sebenarnya tidak memiliki arti yang jelas. Hal ini dapat dikatakan bahwa pragmatik merupakan salah satu pembelajaran makna yang disampaikan penutur kemudian ditafsirkan mitra tutur menurut konteks yang ditangkap olehmitratutur.Karikaturadalahgambar bersifat lelucon yang mengandung sindiran. Karikatur berasal dari bahasa Italia caricatura (caricare) yang artinya memberi muatan atau beban tambahan. Rekaannya adalah tokoh-tokoh politik atau orang-orang yang karena sebuah peristiwa menjadi pusat perhatian. Distorsi jasmani tokoh-tokohnya itu tidak selamanya dimaksudkan sebagai sindiran melainkan dapat juga hanya untuk menampilkannya secara humoristis (Wijana,1995:8). Karikatur biasanya diciptakan sebagai reaksi terhadap peristiwa tertentu sehingga memungkinkan digali atau dicari isi faktanya. Karakteristik karikatur humor selalu mengumpan rasa lucu. Banyak fungsi bisa dijalankan oleh seni karikatur ,antara lain mengritik, menyindir, mengejek, menyarankan, memerintah, menertawai, menghibur, dan berlucu-lucu, menanggapi suatu peristiwa aktual di masyarakat.

Pengekspresian gagasan, peranan, ide, dan bentuk alat yang digunakan dalam karikatur humor dapat berwujud tuturan. Tuturan yang dipergunakan di dalam kerangka pragmatik merupakan bentuk dari tindak tutur. Oleh karena itu, tuturan yang dihasilkan merupakan produk dari tindak ucap. Setiap tuturan atau ujaran dalam berkomunikasi selalu berkaitan erat dengan komponenkomponen tutur. Namun, hal ini tidak selalu komponen tutur tersebut muncul dalam sebuah tuturan (Supriyadi, 2011:25). Tuturan yang terdapat dalam sebuah karikatur penuh dengan perlambangan-perlambangan yang kaya makna. Penggunaan bahasa dalam karikatur memiliki kaidah dan fungsi kompleks. Bahasa karikatur tidak lepas dari kaidah dan fungsi bahasa sebagaimana fungsi komunikatif bahasa yang digunakan dalam berkomunikasi. Seorang karikaturis dalam membuat sebuah karikatur harus dapat menggunakan bahasa yang tepat untuk menyampaikan gagasan, ide, maupun pesannya. Penggunaan bahasa yang tepat itu berkaitan erat dengan penggunaan jenis dan macam tindak tutur yang tepat sehingga pembaca 
dapat memahami gagasan, ide, maupun pesan kritik sosial yang hendak disampaikan karikaturis. Tuturan dalam karikatur juga dipengaruhi oleh kondisi sosial budaya masyarakatnya sehingga fenomena-fenomena yang terjadi di masyarakat merupakan salah satu sumber ide pembuatan karikatur. Tuturan yang terdapat di dalamnya pun mempunyai berbagai maksud yang diungkapkan dengan berbagai jenis dan macam tindak tutur. Karikatur sebagai salah satu bentuk opini gambar sebenarnya merupakan maskot dari sebuah surat kabar karena merupakan versi lain dari editorial atau tajuk rencana dalam versi gambar humor (Sobur, 2006:139).

Wijana (2004) mengatakan bahwa karikatur secara sengaja menciptakan tuturan yang menyimpangkan prinsipprinsip dan parameter pragmatik secara langsungataulewatperantaratokohatau tokoh-tokoh rekaannya yang berperan sebagai peserta tindak tutur yang irasional. Sebagai tokoh yang irasional, figur ini mengutarakan kontribusinya secara berlebih-lebihan atau kurang informatif. Tuturan yang dihasilkannya kerapkali tidak disertai bukti-bukti yang memadai, tidak relevan, dan disampaikan dengan cara-cara bertutur yang tidak semestinya. Pendekatan karikatur terhadap kenyataan faktual sedemikian rupa sampai mampu membuat distorsi terhadap kenyataan. Secara sengaja, karikatur diciptakan untuk fungsi sebagai cermin yang bisa memantulkan tingkah laku setiap orang baik secara pribadi maupun sosial dalam percaturan hidup di masyarakat. Peristiwa-peristiwa aktual suatu kehidupan sosial dapat direkam melalui karikatur dengan kekhasannya menggunakan wacana singkat, padat, penuh makna, menggelitik, dan penuh sindiran yang ditujukan terhadap kebijakan-kebijakan publik (Sudarta, 1980).

Dalam sebuah karikatur, untuk sampai pada pemahaman humor yang sebenarnya, hal yang perlu dilacak adalah berbagai jenis tindak tutur, fungsi pragmatis, implikatur percakapan dan kategorinya yang dikandung oleh berbagai jenis tuturan dalam wacana karikatur tersebut. Tindak tutur adalah produk atau hasil dari suatu kalimat dalam kondisi tertentu dan merupakan kesatuan terkecil dari komunikasi linguistik yang dapat berwujud pernyataan, perintah, pertanyaan, atau lainnya (Searle, 1969). Implikatur merupakan sesuatu yang terimplikasi di dalam suatu percakapan, yaitu sesuatu yang dibiarkan implisit di dalam penggunaan bahasa secara aktual. Implikatur yang ada dalam wacana karikatur humor menunjukkan misi tersembunyi yang melatarbelakangi karikaturis dalam mengkritik dengan cara tidak langsung dan tidak eksplisit sehingga yang diinginkan oleh karikaturis dapat menjadi bahan renungan bagi sasaran kritiknya. Fungsi pragmatis adalah fungsi yang diacu oleh maksud tuturan di dalam pemakaiannya untuk 
berkomunikasi antarpenutur, fungsi pragmatis ini berfungsi menunjang pengungkapan humor. Karikatur merupakan salah satu bentuk praktik kebahasaan yang secara loyal mengikuti prinsip kehematan dan kejelasan (transparansi). Penyampaian pesan di dalamnya menggunakan kata-kata yang sedikit namun mempunyai ketajaman pesan yang dapat digunakan untuk menyampaikan kritik dan sindiran yang dapat dipertanggungjawabkan kualitasnya(Rahardi,2009:34). Menurut Sibarani (2001:10), karikatur dibagi menjadi tiga macam. Pertama adalah karikatur orang pribadi, yaitu karikatur yang menggambarkan seseorang (biasanya tokoh terkenal) dengan mengekspos ciri-cirinya dalam bentuk wajah ataupun kebiasaannya tanpa objek lain atau situasi di sekelilingnya. Kedua adalah karikatur sosial, yaitu karikatur yang menggambarkan serta mengemukakan persoalan-persoalan yang menyinggung rasa keadilan social. Ketiga adalah karikatur politik, yaitu karikatur yang menggambarkan situasi politik sedemikian rupa agar dapat dilihat dari segi humor dengan menampilkan para tokoh politik di atas panggung dan mementaskannya secara lucu. Melalui analisis terhadap hal-hal yang disampaikan karikatur, pembaca dapat mereka-reka misi yang diemban sebuah media serta tujuan-tujuan tertentu yang hendak dicapai. Karikatur sering ditampilkan dengan gambargambar lucu dan menarik serta diikuti dengan teks singkat yang sebetulnya merupakan sebuah bentuk opini penerbit yang terdapat dalam media massa. Opini tersebut jelaslah berasal dari fenomena yang terjadi pada suatu masyarakat atau sesuatu yang populer dengan tujuan sebagai ungkapan kritis atas realitas yang berkembang. Pembaca diajak untuk berfikir, merenungkan, dan memahami pesan-pesan yang tersurat dan tersirat dalam gambar tersebut (Sobur, 2006:140).

Berkaitan dengan analisis pragmatik dalam kajian ini yaitu pengungkapan maksud isi tuturan secara benar, Searle (dalam Wijana 1996: 17) mengemukakan bahwa secara pragmatis setidak-tidaknya ada tiga jenis tindakan yang dapat diwujudkan oleh seorang penutur, yakni tindak lokusi, (locationary act), ilokusi (illocutionaryact), dan tindak perlokusi (perlocutionary act). Tindak lokusi adalah tindak tutur untuk menyatakan sesuatu. Tindak ilokusi adalah sebuah tuturan yang berfungsi untuk melakukan sesuatu. Tindak perlokusi adalah tindak tutur yang pengutaraannya dimaksudkan untuk mempengaruhi lawan tutur (Wijana, 1996:17). Selain itu, berdasarkan modus kalimatnya, tindak tutur dapat dibedakan menjadi tindak tutur langsung, tindak tutur tidak langsung, tindak tutur literal, dan tindak tutur tidak literal. Tindak tutur langsung adalah tindak tutur yang terbentuk dari kalimat yang digunakan sesuai dengan konvensinya; tindak tutur tidak langsung adalah tindak tutur yang terbentuk dari kalimat yag digunakan 
tidak sesuai dengan konvensinya. Tindak tutur literal adalah tindak tutur yang sama maksudnya dengan makna kata yang menyusunnya, sedangkan tindak tutur tidak literal adalah tindak tutur yang maksudnya tidak sama dengan atau berlawanan dengan katakata penyusunnya (Wijana, 1996:30).

\section{HASIL DAN PEMBAHASAN}

\section{Pemanfaatan Bahasa dan Koherensi} Unsur Lingual dalam Karikatur Humor

Pemanfaatan aspek kebahasaan atau unsur-unsur lingual menurut Soewandi (1995) adalah berdasarkan asas kebahasaan. Ragam bahasa dapat dibagi menjadi dua ragam yakni ragam lengkap dan ragam tidak lengkap. Suatu wacana termasuk ragam lengkap apabila wacana itu sebagai suatu keutuhan memiliki ciri-ciri yang khusus dan lengkap. Ciri-ciri tersebut mencakup semua unsur-unsur kebahasaan seperti penulisan dan ejaan, lafal, kosakata, bentuk dan jenis, pembentukan kata, pembentukan frasa, penggunaan kalimat dan wacana, yang termasuk ragam lengkap adalah ragam bahasa untuk menyampaikan ilmu pengetahuan, fakta, opini, dan pemberitaan, dan ragam bahasa untuk menyampaikan hal yang bersifat ekspresif. Dalam hal ini, wacana karikatur termasuk wacana lengkap karena tuturan dalam karikatur memanfaatkan berbagai unsur kebahasaan seperti penulisan ejaan, kosakata (bentuk dan jenis), pembentukan kata, pembentukan frasa, pembentukan kalimat dan wacana. Berikut ini dijelaskan pemanfaatan aspek-aspek kebahasaan pada data berikut ini.

\section{Pemanfaatan aspek fonologi (bunyi)}

Bunyi merupakan satuan

kebahasaan terkecil. Bunyi-bunyi bahasa secara garis besar dapat dibedakan menjadi dua jenis yaitu fon dan fonem. Semua bunyi bahasa dengan tidak mempertimbangkan kapasitasnya sebagai pembeda maknanya yang disebut fon. Fonem sebagai unsur esensial memiliki peranan yang bersifat sistematik dan struktural. Peranannya yang bersifat sistemik mengakibatkan bunyi-bunyi itu bersifat distingtif di dalam susunan berlanjur. Perananyang bersifat struktural mengakibatkannya bersifat distingtif di dalam susunan beruntun. Culler (dalam Wijana, 1995) menyebut susunan beruntun yang dimaksud di sini sebagai hubungan sintagmatik, dan susunan berlajur sebagai hubungan paradigmatik. Misalnya, kata "pagi" dan "bagi” memiliki perbedaan makna karena peranan /p/ dan /b/ yang paradigmatik. Kata "alir", "liar", "lari", dan "lira" masingmasing memiliki makna yang berbeda karena kedistingtifan bunyi-bunyinya yang sintagmatik (Wijana, 1995:153). Berdasarkan sifat-sifat bunyi yang telah disebutkan, hal itu dimanfaatkan oleh karikaturis dalam karikaturnya. Berikut disajikan contoh datanya. 
a. Aspek peninggian dan pemanjangan bunyi

Karikatur 1

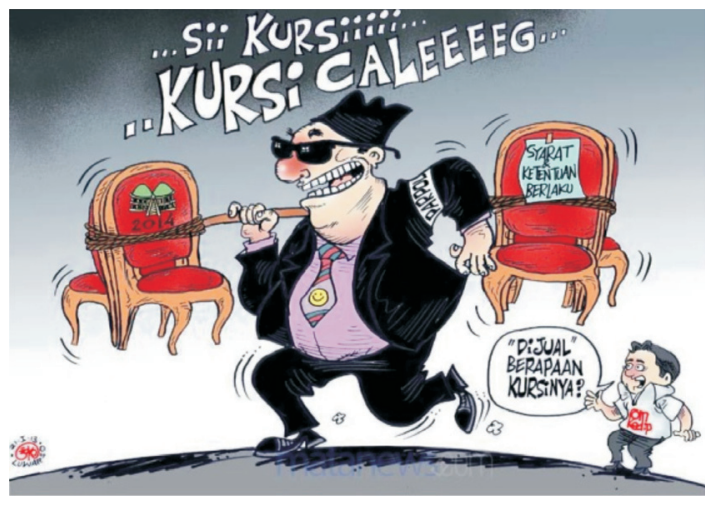

Data karikatur (1) memanfaatkan aspek kebahasaan yang berwujud bunyi, yaitu peninggian dan pemanjangan bunyi. Aspek peninggian dan pemanjangan bunyi dalam oleh karikaturis dimaksudkan sebagai bentuk mengkritik pernyataan seorang calon legislatif dalam partai politik yang sedang memperebutkan kursi jabatan dalam pemilihan legislatif. Karikaturis melaluigambar karikaturnya menirukan ucapan seorang calon legislatif dengan menanggapi peristiwa yang terjadi perihal perebutan kursi jabatan oleh seorang calon legislatif tersebut.

Kata "Sii Kursiii... Kursi Caleeeg" memaknakan sesuatu seperti menawarkan barang dagangan dalam bentuk kursi. Data (1) tersebut terdiri dari kumpulan kata-kata dengan aspek peninggian dan pemanjangan bunyi "Sii Kursiii...Kursi Caleeeg". Namun, dat itu memiliki implikasi yang sangat dalam karena mengandung unsur menyepelekan atau meremehkan dengan bentuk penawaran barang dalam bentuk kursi. Konteks yang melatarbelakangi adalah di dunia politik. Istilah "berebut kursi" sering dipakai untuk meramaikan pemilihan umum (pemilu). Istilah itu bukan harfiah atau perumpamaan, dia benarbenar "sekadar" berebut kursi dalam arti sebenarnya. Dikatakan kursi karena dia memberi tempat bagi kegiatan manusia yang sangat khas yaitu duduk. Sebab,kursi dikonotasikan sebagai pejabat baik di legislatif, eksekutif maupun yudikatif yang semuanya hanyalah seonggok kekuasaan. Dalam dunia politik, kursi diartikan sebagai kekuasaan, dalam hal ini pada pemilihan umum (Pemilu), proses pemilihan orang-orang untuk mengisi jabatanjabatan politik tertentu. Tuturan dibawahnya adalah "Di jual berapaan kursinya". Tuturan ini menyatakan bahwa konteks yang melatarbelakangi adalah perebutan kursi jabatan tersebut. Perebutan kursi kekuasaan sejak era reformasi 1998 telah membuka ruang baru untuk berbagai macam jabatan baik dipilih langsung oleh rakyat melalui pemilihan umum atau dengan sistem ditunjuk untuk menduduki kursi jabatan tertentu. Perebutan kursi kekuasaan akhir-akhir ini menjadi sebuah tontonan yang terkadang sudah mulai menjemukan disebabkan cara untuk mendapatkan tempat duduk untuk menjalankan kekuasaan sudah mulai menggunakan cara-cara yang tidak manusiawi dan mengingkari nilai agama. Pada hakikatnya, seorang pemimpin dan memiliki sebuah jabatan 
merupakan impian semua orang kecuali sedikit dari mereka yang dirahmati oleh Tuhan. Mayoritas orang justru menjadikannya sebagai ajang rebutan, khususnya jabatan yang menjanjikan uang dan harta serta kesenangan dunia lainnya. Cara mendapatkannya juga dengan menggunakan berbagai intrik atau siasat untuk mendapatkan kursi jabatan tersebut. Namun, hal yang perlu dipahami bahwa dibaliknikmatnya kursi jabatan yang penuh dengan prestise dan uang, jabatan memiliki tanggung jawab besar baik kepada Tuhan maupun yang memberi amanah tersebut.

Data karikatur (1) tersebut menunjukkan adanya tindak tutur komisif. Tindak tutur komisif merupakan tindak tutur yang menyebabkan penutur melakukan serangkaian kegiatan. Verba tindak tutur komisif ditandai dengan verba menawarkan yaitu "Sii Kursiii... Kursi Caleeeg". Data karikatur (1) berjenis tindak tutur komisif dengan fungsi menawarkan karena ada seseorang atau sebuah partai politik yang menawarkan untuk membantu dalam memenangkan jabatan dengan berbagai macam cara. Dalam fungsi ini, tugas partai polotik adalah merumuskan program politik yang mencerminkan gabungan tuntutan-tuntutan dari partai-partai politik yang ada dalam pemerintahan dan menyampaikannya kepada badan legislatif. Selain itu, partai politik juga melakukan tawar-menawar dengan calon-calon pejabat pemerintah yang diajukan dalam bentuk penawaran pemberian dukungan bagi caloncalon pejabat pemerintah dengan imbalan pemenuhan kepentingankepentingan partai politik. Bentuk penawaran tersebut dijelaskan dengan gambar seseorang dengan membawa kursi, kemudian ada beberapa calon pejabat yang tertarik dengan penawaran tersebut. Berdasarkan cara penyampaiannya, data karikatur (1) berjenis tindak tutur langsung tidak literal (directnonliteral speech act),yakni tindak tutur yang diutarakan dengan modus kalimat yang sesuai dengan maksud tuturan, tetapi kata-kata yang menyusunnya tidak memiliki makna yang sama dengan makna penuturnya. Maksud menginformasikan atau memberitakan dengan menggunakan kalimat berita (deklaratif) yang diungkapkan dalam kalimat "Sii Kursiii... Kursi Caleeeg". Maksud yang terkandung dalam tindak tutur langsung tidak literal tokoh dalam data tersebut yaitu menawarkan dukungan melalui partai politik untuk setiap calon legislatif yang akan mengikuti proses pemilihan umum. Selanjutnya, kalimat "Di jual berapaan kursinya?" merupakan tindak tutur langsung literal (direct literal speech act) adalah tindak tutur yang diutarakan dengan modus tuturan dan makna yang sama dengan maksud pengutaraannya. Maksud bertanya disampaikan dalam kalimat tanya (interogatif). Hal ini dimaksudkan bahwa seorang calon pejabat bertanya mengenai perihal dukungan yang ditawarkan oleh sebuah partai politik dalam proses pemilihan 
legislatif yang diiukutinya. Penawaran dukungan tersebut diharapkan dapat membantu melancarkan terpilihnya calon pejabat tersebut.

b. Aspek onomatope

\section{Karikatur 2}

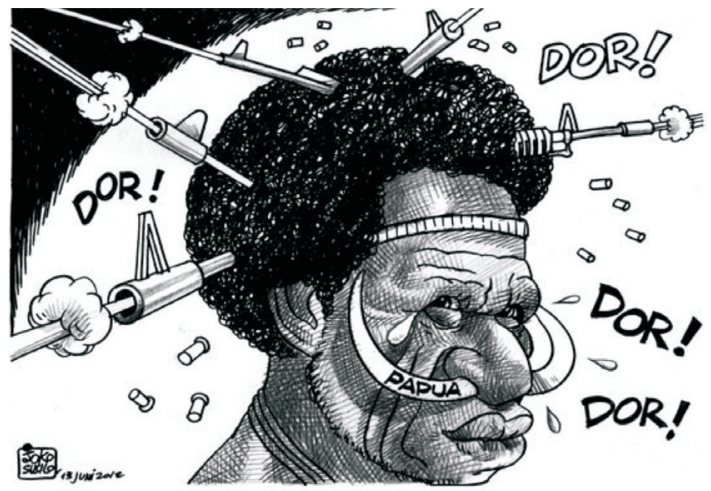

Data dalam karikatur (2) "Dor!... Dor!...Dor!...Dor!...Dor!" memanfaatkan bunyi tiruan atau onomatope. Onomatope adalah tiruan bunyi dari suara alat atau suara hewan. Tiruan bunyi (onomatope) sebagai bukti ada hubungan yang normal atau alamiah antara kata dan referensinya (Gorys Keraf, 1985:85). Onomatope merupakan kata-kata tiruan di mana fonem-fonem direpresentasikan dengan cara yang kurang lebih sesuai dengan bunyi aslinya seperti bunyi yang dihasilkan oleh benda yaitu alat tembak berupa senapan yang berbunyi "Dor". Ullman (2007:104) menyatakan bahwa onomatope melibatkan suatu hubungan intrinsik antara nama dan makna.

Tiruan bunyi yang dimanfaatkan karikaturis adalah suara senapan pistol. Pemilihan tiruan bunyi senapan tersebut merupakan bentuk peperangan dari suku yang ada di Papua. Konteks data karikatur (2) adalah perselisihan antarsuku di Timika, Papua, yang memanas beberapa bulan lalu, dan kembali pecah dengan ditandai bentrok yang berdurasi dua jam. Dua kelompok yang berseteru saling serang dengan menggunakan senjata tradisional panah dan parang. Perang suku tersebut dihentikan oleh aparat dengan melakukan tembakan peringatan serta tembakan gas air mata kearah dua kelompok warga. Setelah tembakan peringatan dan gas air mata, kedua kelompok akhirnya membubarkan diri. Semua pihak harus mencari solusi untuk menghentikan perang agar tidak berkepanjangan.

Data karikatur (2) "Dor!...Dor!... Dor!...Dor!...Dor!" berjenis tindak tutur direktif dengan isi tuturan berwujud kalimat perintah (imperatif). Tindak tutur direktif merupakan tindak tutur dimana penutur dalam hal ini tokoh yang ada dalam karikatur tersebut berusaha meminta mitra tutur untuk melakukan perbuatan atau tidak melakukan perbuatan. Tindak tutur direktif bersifat prospektif, artinya seseorang tidak bisa menyuruh orang lain dalam suatu perbuatan pada masa lampau. Berdasarkan cara penyampaiannya, data karikatur tersebut berjenis tindak tutur langsung literal (direct literal speech act) karena yang dituturkan sama dengan yang dimaksudkan, yaitu telah terjadi baku tembak antarsuku yang ada di Timika, Papua. Dalam kehidupan masyarakat, konflik merupakan hal yang wajar dan biasa karena setiap individu memiliki kepentingan yang 
berbeda-beda dan ketika kepentingan kelompok dengan kelompok saling berbenturan maka terjadilah konflik. Pada dasarnya, munculnya konflik tidak lepas dari kehidupan suatu masyarakat karena konflik merupakan suatu fenomena yang tidak dapat dihilangkan dalam suatu interaksi sosial. Konflik hanya dapat dikendalikan dan diminimalisasi saja sehingga konflik yang timbul tidak sampai mengancam kehidupan bermasyarakat, berbangsa, dan bernegara. Selanjutnya, implikatur daya pragmatik adalah perselisihan antarsuku di Timika, Papua, yang kembali terjadi. Daya pragmatik adalah efek pragmatik yang dimiliki dari sebuah tuturan. Dalam hal ini, daya pragmatik bertumpu pada semantik tuturan sekaligus mempertimbangkan konteks dalam arti tempat terjadinya tuturan itu serta tradisi-tradisi dan adat kebiasaan dalam masyarakat tutur itu. Berkaitan dengan daya pragmatik, konteks data karikatur (2) adalah konflik antarsuku di Timika, Papua. Hal itu bukan daerah Timika jika tak ada kekacauan, bentrok atau kerusuhan. Sebagai contohnya adalah konflik antara PT Freeport Indonesia dengan warga setempat dan konflik di Timika antara masyarakat dengan pemerintah. Gejala timbulnya pertikaian antarsuku di Papua kini bukan hanya akibat struktur sosial budaya setempat, melainkan bisa terjadi akibat mengakarnya faham kago (ratu adil) yang secara psikologis membentuk perilaku konflik ketimpangan pembangunan dan kehidupan sosial ekonomi. Penyebab konflik di Papua antara lain, banyaknya warga pendatang baru yang berasal dari Papua, rendahnya tingkat pendidikan dan kesehatan di Papua, kalangan pemuda yang tidak menuruti ketua adat, provokasi yang dilakukan oleh pihak-pihak yang tidak bertanggung jawab, dan yang paling sering terjadi masih adanya budaya balas dendam di masyarakat Papua.

\section{Pemanfaatan aspek kebahasaan bentuk kata}

a. Kata-kata yang bermakna polisemi

Kata-kata yang ada dalam suatu bahasa jumlahnya jauh lebih terbatas bila dibandingkan dengan konsep-konsep yang hendak atau mungkin dikomunikasikan oleh penutur-penuturnya. Sehubungan dengan hal ini, sejumlah konsep yang memiliki ciri semantik sama atau beberapa ciri sama memiliki kemungkinan diungkapkan dengan tanda (leksem) yang sama (Sudira dalam Wijana, 1995:166). Leksem yang memiliki perbedaan makna yang disebabkan oleh konteks pemakaiannya disebut polisemi. Di dalam leksikografi, kata yang bermakna polisemi dimasukkan ke dalam satu entri yang sama beserta berbagai kemungkinan maknanya. Karikaturis juga memanfaatkan kata yang mengandung makna ganda dalam teks yang menyertai gambar karikaturnya, dengan harapan apa yang terkandung di 
dalam makna teks dapat ditafsirkan oleh pembaca lebih dalam dengan berbagai tafsiran.

\section{Karikatur 3}

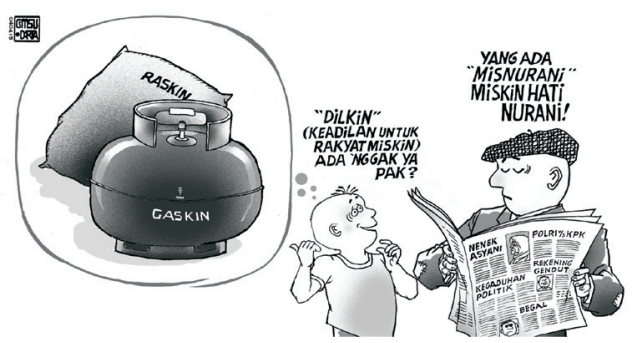

Data dalam karikatur (3) yang menunjukkan kata "Miskin". Kata "Miskin" merupakan kata yang bermakna polisemi karena kata tersebut mempunyai perbedaan makna yang disebabkan perbedaan konteks pemakaiannya. Miskin menurut KBBI (Kamus Besar Bahasa Indonesia) adalah tidak berharta, serba kekurangan (berpenghasilan sangat rendah). Gambar karikatur (3), yaitu kemiskinan, merupakan situasi penduduk atau sebagian penduduk yang hanya dapat memenuhi makanan, pakaian, dan perumahan yang sangat diperlukan untuk mempertahankan tingkat kehidupan yang minimum. Berkaitan dengan konteks di atas, polisemi dari kata miskin adalah "raskin dan gaskin". Raskin merupakan subsidi pangan dalam bentuk beras yang diperuntukkan bagi rumah tangga berpenghasilan rendah sebagai upaya dari pemerintah untuk meningkatkan ketahananpangan dan memberikan perlindungan sosial pada rumah tangga sasaran. Sama halnya dengan gaskin yang merupakan subsidi dalam bentuk gas untuk rakyat kurang mampu. Karikatur pada data (3) menyebutkan kata raskin dan gaskin yang identik dengan kemiskinan menandakan bahwa barang-barang tersebut diperuntukkan bagi rakyat miskin. Apakah hal tersebut berkaitan juga dengan miskinnya keadilan dan hati nurani yang dimiliki oleh rakyat miskin? Tentu saja tidak, hal ini hanya merupakan asumsi sebagian kecil rakyat dalam menginterpretasikan hal tersebut.

Data karikatur (3) "Dilkin (keadilan untuk rakyat miskin) ada nggak ya?" berjenis tindak tutur komisif. Tindak tutur komisif merupakan tindak tutur yang menyebabkan penutur melakukan serangkaian kegiatan. Dikatakan berjenis tindak tutur komisif karena pada isi tuturan menggunakan verba bertanya mengenai ada atau tidaknya keadilan untuk rakyat miskin. Tuturan ini dilontarkan karena mendapatkan bantuan hukum merupakan hak asasi yang dimiliki oleh setiap orang. Hak asasi tersebut merujuk pada syarat setiap orang untuk mendapatkan keadilan tidak peduli kaya atau miskin. Setiap warga negara sama kedudukannya di dalam hukum dan pemerintahan, dan wajib menjunjung tinggi hukum dan pemerintahan itu 
dengan tidak ada kekecualian. Namun dalam kenyataannya, keadilan bagi rakyat miskin tidak pernah ada. Selanjutnya, tuturan "Yang ada 'misnurani' miskin hati nurani" dapat dimasukkan dalam jenis tindak tutur verdiktif. Tindak tutur verdiktif merupakan tindak tutur di mana penutur membuat penilaian atas tindakan orang lain, yaitu penutur menilai perbutan orang lain. Dalm hal ini, penilaian mengenai kemiskinan yang masih ada di Indonesia. Kemiskinan terjadi akibat dari ketidakadilan. Penegakan hukum di negara Indonesia masih sangat diskriminatif, keras, dan tegas untuk rakyat kecil, tetapi lemah dan seperti agar-agar untuk kalangan atas. Hal ini sangat bertentangan dengan negara yang katanya negara hukum, namun keadilan tetap masih belum bisa dirasakan oleh semua lapisan masyarakat.

Berdasarkan cara penyampaiannya data karikatur (3) "Yang ada 'misnurani' miskin hati nurani" berjenis tindak tutur langsung tidak literal (direct nonliteral speech act). Tindak tutur langsung tidak literal adalah tindak tutur yang diutarakan dengan modus kalimat yang sesuai dengan maksud tuturan, tetapi kata-kata yang menyusunnya tidak memiliki makna yang sama dengan maksud penuturnya. Hal tersebut dapat dilihat dengan penanda lingual "misnurani" yang mempunyai makna berbeda dengan yang dimaksudkannya. Dalam hal ini, bahaya terbesar dari kemiskinan bukan terletak pada miskin secara fisik tetapi miskin dalam jiwa, hati, dan moral manusia. Implikatur data karikatur (3) adalah diharapkan penegakan hukum mampu melahirkan proses keadilan. Namun, kenyataannya hukum di Indonesia saat ini hanya menguntungkan mereka yang ada, yaitu kelompokkelompok menengah ke atas dan kelompok-kelompok orang miskin selalu mendapat imbas dari ketidakadilan tersebut. Selanjutnya, daya pragmatiknya adalah adanya pejabat atau petinggi negara yang korupsi dengan hanya mendapat hukuman yang tidak setimpal dengan perbuatannya, sedangkan seorang nenek yang dituduh mencuri pohon jati di lahannya sendiri sampai dijatuhi hukuman yang berat. Sungguh, hal ini merupakan ketidakadilan yang sering terjadi di negara. Keadilan hanya untuk orang yang kaya, tetapi orang miskin selalu direndahkan dan ditindas. Penegak hukum selalu berbicara keadilan, namun pada kenyataannya mereka sendirilah yang melanggar hukum tersebut. 


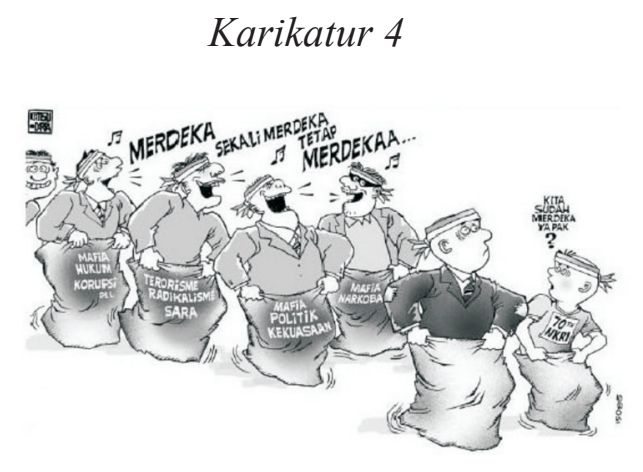

Data karikatur (4) tersebut menunjukkan tuturan "Merdeka sekali merdeka tetap merdeka". Salah satu kata mempunyai makna polisemi adalah kata "Merdeka". Sebab, kata tersebut mempunyai perbedaan makna yang disebabkan oleh konteks pemakaiannya. Menurut KBBI, merdeka adalah bebas (dari perhambatan, penjajahan). Menurut konteksnya, hal ini adalah bangsa Indonesia yang merupakan negara terjajah selama tujuh puluh satu tahun yang lalu. Hal ini mempunyai makna terbebas dari belenggu penjajah. Merdeka dalam konteks perbudakan yang mempunyai makna bebas dari majikan yang membelinya. Merdeka berarti bebas. Kemerdekaan berarti kebebasan dan kesejahteraan. Pemahaman sebagai rakyat dalam arti merdeka adalah terlepas dari semua belenggu kehidupan sebagai pribadi dan sebagai bangsa.

Kata "Merdeka sekali merdeka tetap merdeka", dalam konteks data karikatur (4), merupakan kritik kepada para mafia yang menjadi terdakwa dalam kasus tertentu. Mafia merujuk pada kejahatan yang terorganisir dengan rapi dan memiliki struktur dan sistem di dalamnya, ada bos besarnya. Di Indonesia, mafia dikaitkan dengan jaringan peredaran narkoba, politik kekuasaan, mafia terorisme radikalisme dan SARA, mafia hukum korupsi, mafia prostitusi, human trafficking, pencucian uang, dan sebagainya. Diantara semua itu, mafia hukumlah yang paling berbahaya karena menjadi pelindung para kriminal. Mafia hukum ini adalah pihakpihak yang mampu dan berkuasa mengendalikan hukum di Indonesia sesuai keinginannya. Berkuasanya organisasi mafia ini, banyak negara yang mengalami kegagalan dalam penumpasan mafia. Kekuatan mafia itu bertumpu pada uang, suap menyuap, jaringan yang solid, anggota yang setia, dan citra kekejaman. Kesetiaan para anggota mafia ini menjadikan aparat hukum kesulitan dalam membongkar kasus-kasus hukum yang melibatkan mafia tersebut.

Data karikatur (4) berjenis tindak tutur asertif. Tindak tutur asertif berkaitan dengan data fakta, pengetahuan yang ada atau telah terjadi. Istilah lain tuturan asertif adalah tuturan representative, yaitu tuturan yang mengikat penuturnya akan kebenaran tuturannya dan harus dapat dibuktikan kebenarannya. Dengan fungsi pragmatis ini, penutur bermaksud 
menyatakan kebenaran sesuatu yang dituturkan. Dalam hal ini, tokoh dalam karikatur tersebut menjelaskan, menyatakan atau mengatakan tentang fakta yang dialaminya, yaitu merdeka atau bebas dari jeratan hukum padahal sebelumya adalah seorang mafia. Tuturan "Merdeka sekali merdeka tetap merdeka" merupakan tuturan asertif karena tuturan tersebut mengikat para mafia selaku penuturnya akan kebenaran tuturannya. Tuturan "merdeka" memiliki fungsi pragmatis yaitu menyatakan. Hal itu terjadi karena tuturan tersebut mengacu kepada maksud ujaran yang memang fungsinya menyatakan merdeka dan bebas dari hukum. Konteks tuturan yang mendukung yaitu bahwa kebebasan di Indonesia dapat dibeli dengan berbagai cara. Berdasarkan cara penyampaiannya, data karikatur (4) berjenis tindak tutur tidak langsung literal (indirect literal speech act), yaitu tindak tutur yang diungkapkan dengan modus kalimat yang tidak sesuai dengan maksud pengutaraannya, tetapi makna kata-kata yang menyusunnya sesuai dengan apa yang dimaksudkan penutur. Dalam tindak tutur data ini, maksud memerintah diutarakan dengan kalimat berita (deklaratif). Konteks data karikatur (4) adalah bahwa kasus hukum yang ada di Indonesia perlu ditegakkan keadilan, tuturan tersebut tidak hanya informasi, tetapi terkandung maksud memerintah yang diungkapkan secara tidak langsung dalam kalimat berita. Makna kata-kata yang menyusunnya sama dengan maksud yang dikandungnya, yaitu merdeka dan bebas dari jeratan hukum. Implikatur dalam data karikatur (4) adalah bahwa di negara Indonesia tidak ada supremasi hukum, tidak ada penegakan hukum yang tegas, benar, dan adil. Selanjutnya, daya pragmatic terletak pada sindiran dan kritik untuk para mafia sebagai tersangka-tersangka kasus tertentu yang merupakan orang kaya, terpandang akan selalu lolos dari jeratan hukum. Sebagai contoh misalnya, mafia hukum terdapat di mana-mana, mulai polres sampai Mabes Polri, dari Pengadialan Negeri sampai Mahkamah Agung. Mafia hukum ini melibatkan aparat penegak hukum yaitu polisi, jaksa, hakim, panitera, dan pengacara. Putusan bebas dan hukuman ringan terhadap terdakwa kasuskasus yang ada di Indonesia selalu ada dan mungkin karena kualitas hukum di pengadilan negeri yang semakin menurun. Keadaan ini harus dibenahi secara serius di berbagai aspek terkait masalah ini, mulai dari dakwaan, tuntutan, hingga kualitas hakim yang akan memeriksa perkara korupsi dan lain-lain. 
b. Kata yang berbentuk idiom

Setiap bahasa tentu memiliki idiom, yakni bentuk kebahasaan yang berupa rangakaian kata-kata yang secara semantik memiliki makna berbeda. Elemen-elemen pembentuk idiom merupakan satu kesatuan (Crystal dalam Wijana, 1995:220). Dalam kajian semantik, makna kata-kata yang berbentuk idiom tidak dapat digabunggabungkanuntukmenghasilkanatau memperoleh makna ungkapan ini secara keseluruhan (Hocket dalam Wijana, 1995:220). Secara sintaksis, idiom tidak menampakkan variasi bentuk seperti layaknya urutan nonidiomatik bila hadir dalam konteks yang lain. Di dalam komunikasi lisan atau bertutur,pemakaian kata dalam masyarakat Indonesia adakalanya memakai idiom untuk memperhalus maksud. Selain itu, adakalanya orang memakai idiom agar tidak menyinggung perasaan orang lain. Bentuk-bentuk kebahasaan yang merupakan idiom diperoleh dan dipersepsikan penutur sebagai satu kesatuan yang tidak terpisahkan dan digunakan dalam situasi khusus. Berikut dicontohkan data karikatur yang menunjukkan idiom. Karikatur 5

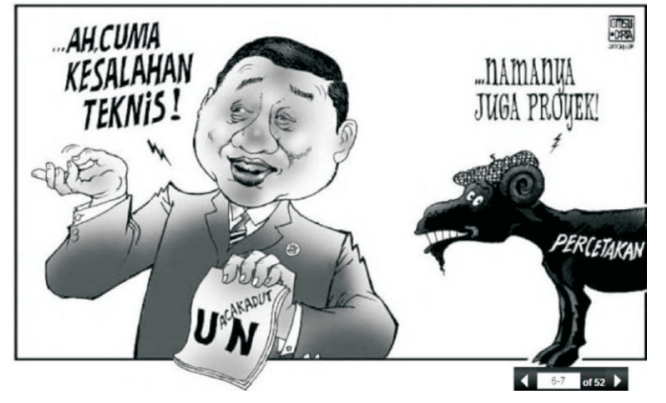

Pemanfaatan aspek kebahasaan yang terlihat dalam data karikatur (5) adalah dalam tataran kata yang berbentuk idiom dan diwujudkan dalam gambar seekor kambing hitam. "Kambing hitam" dapat dikatakan sebagai "orang atau sesuatu" yang disalahkan. Makna idiom ini jauh berbeda maknanya apabila dibandingkan dengan seekor binatang kambing berwarna hitam dalam arti sebenarnya. Gambar kambing hitam yang dimaksudkan adalah sebuah perusahaan percetakan yang menggandakan soal Ujian Nasional (UN). Pemilihan idiom dalam karikatur tersebut menjelaskan mengenai penyelenggaraan UN yang tidak dapat dilaksanakan serentak. Hal ini disebabkan soal ujian tidak bisa didistribusikan tepat waktu karena perusahaan percetakan gagal memenuhi target waktu penyelesaian percetakan naskah ujian sesuai kesepakatan. Kasus seperti ini biasanya tidak pernah terjadi karena waktu persiapannya cukup lama dan pemerintah, khususnya Kementerian Pendidikan dan Kebudayaan (Kemdikbud) telah berpengalaman menyelenggarakannya. Kata "Acakadut UN" dalam karikatur tersebut menyatakan bahwa pelaksanaan UN yang tidak bisa dilaksanakan serentak membuktikan manajemen dan lemahnya 
pengawasan Kemdikbud dan menganggap hanya sebuah kesalahan teknik saja. Selanjutnya, kata "Namanya juga proyek" menyatakan bahwa pelaksanaan UN juga masih dipandang sebagai proyek oleh pejabat tertentu. Proyek penggandaan dan distribusi soal-soal UN merupakan proyek untuk mendapatkan uang. Saat proses tender berlangsung, Direktur Investigasi dan

Advokasi Forum Indonesia untuk Transparansi Anggaran telah mencium kejanggalan salah satunya adalah pejabat Kemdikbud yang memenangkan PT Ghalia sebagai percetakan dengan tawaran $\mathrm{Rp}$ 22,4 miliar dan mengalahkan perusahaan lain yang mengajukan penawaran Rp 17,1 miliar. Oleh karena itu, hal ini perlu mendesak Inspetorat Kemdikbud, Badan Pemeriksa Keuangan (BPK) dan Komisi Pemberantasan Korupsi (KPK) turun tangan menyelidiki kemungkinan kerja sama pejabat Kemdikbud yang berpotensi merugikan keuangan negara.

Data di atas mengatakakan bahwa pemanfaatan bentuk idiom dimaksudkan oleh karikaturis sebagai tuturan singkat tapi padat artinya. Idiom dalam data karikatur (5) dianggap sudah mewakili maksud karikaturis karena didukung dengan gambar figur seseorang yang mempunyai jabatan kemudian menuturkan bahwa UN yang "acakadut" hanya merupakan kesalahan teknis saja. Namun, hal itu merujuk kepada sebuah perusahaan percetakan yang dipercaya dalam penggandaan naskah. Hal ini diperkuat dengan adanya ikon kambing yang berwarna hitam sebagai inti kritik yaitu banyak tokoh masyarakat yang mengambil keuntungan dari proyek-proyek tertentu. Pemanfaatan kata idiom dalam aspek kebahasaan dimaksudkan sebagai ungkapan kata berkonotasi lebih baik dan simbolis supaya sasaran kritiknya tidak merasa disakiti atau tersinggung setelah membaca isi kata-kata yang ada dalam karikatur tersebut. Hal ini sama seperti dikutip dalam pernyataan Lyons(dalam Wijana, 1995:221), bahwa karikatur dalam penyajian karikatur verbal juga memanfaatkan kata yang berbentuk idiom dalam karikaturnya.

Data karikatur (5), kalimat " $A$... cuma kesalahan teknis" merupakan tindak tutur performatif. Tindak tutur performatif adalah tindak tutur yang menyebabkan resminya sesuatu yang dinamakan. Tuturan performatif menjadi sah jika dinyatakan oleh seseorang yang berwenang dan dapat diterima secara umum. Ada syarat-syarat tertentu yang harus dipenuhi dalam tindak tutur performatif. Pertama, subjek kalimat harus saya atau kami. Kedua, verba harus dalam 
bentuk kala kini dan yang paling penting adalah penutur tersebut harus diketahui memiliki otoritas untuk membuat pernyataan dan situasinya harus cocok. Tindak tutur performatif dalam data tersebut merupakan tuturan yang isinya menyatakan dan mengumumkan perihaladanyakesalahan teknisyang dilakukan oleh sebuah percetakan yang memenangkan tender dalam penggandaan naskah soal ujian. Pernyataan dan pengumuman ini yang memegang otoritas adalah salah satu pejabat Kemdikbud yang memegang peranan penting dalam proses pelaksanaan ujian nasional. Selanjutnya, dalam gambar, seekor kambing hitam yang dikonotasikan juga menyatakan pendapatnya dengan kalimat "Namanya juga proyek". Berdasarkan cara penyampaiannya, kalimat tersebut berjenis tindak tutur langsung literal (direct literal speech act). Tindak tutur langsung merupakan tindak tutur yang diutarakan dengan modus tuturan dan makna yang sama dengan maksud pengutaraannya. Maksud memberitakan disampaikan dengan kalimat berita (deklaratif). Tuturan tersebut merupakan tindak tutur yang dimaksudkan untuk memberitakan bahwa perusahaan percetakan tersebut menganggap ini hanyalah akal-akalan para pejabat yang mengambil keuntungan dalam proses penggandaan naskah soal ujian. Implikatur dan daya pragmatik dalam data karikatur (5) terdapat sebuah perusahaan percetakan yang merupakan perusahaan titipan yang dimenangkan oleh salah satu pejabat di Kemdikbud. Komisi X DPR juga terlibat karena oknum anggota komisi ini yang merupakan bagian dalam proses lelang naskah soal UN tersebut. Namun, percetakan tersebut menyangkal bahwa pengerjaan naskah soal UN pada tahun ini cukup menyulitkan karena adanya 30 variasi paket soal, ditambah lagi masalah durasi waktu percetakan soal yang dinilai terlalu singkat dan kapasitas gudang yang dimiliki tidak cukup besar untuk menampung jutaan eksemplar soal yang selesai dicetak. Hal ini menimbulkan pertanyaan, mengapa perusahaan dengan integritas dan kemampuan produksi seperti itu dapat terpilih dalam jajaran pemenang tender yang lain. Daya pragmatik data karikatur (6) adalah sindiran terhadap pejabat yang menganggap hal tersebut merupakan sebuah proyek korupsi yang dilakukan. Tuturan ketidaksenangan penutur (percetakan) tersebut dinyatakan dalam penanda lingual "Namanya juga proyek". Pada saat itu, percetakan yang memenangkan tender dalam penggandaan naskah soal UN merasa dikambinghitamkan dalam kasus tersebut. 
Gita Anggria Resticka - Pemanfaatan Aspek Kebahasaan Bentuk Kata Tuturan...

\section{SIMPULAN}

Karikatur adalah gambar yang mempunyai fungsi sebagai media kritik dan hiburan atau humor. Hal tersebut diperkuat berdasarkan pemahaman karikaturis dan pembaca karikatur tentang fungsi kemasyarakatan yang terkandung di dalam karikatur. Sebuah karikatur memiliki keterkaitan antara tema, aspek kebahasaan, citra, dan gambar sehingga koheren dan memiliki kesatuan makna dalam bingkai konteks ideologi, politik, ekonomi, soial, budaya, hankam dan pendidikan serta dapat tampil utuh sebagai karya karikatur. Pemanfaatan aspek kebahasaan dalam data penelitian ini meliputi pemanfaatan aspek fonologi dengan aspek peninggian atau pemanjangan bunyi dan aspek onomatope. Selain itu, ada pula pemanfaatan aspek kebahasaan dengan kata-kata yang bermakna polisemi dan yang berbentuk idiom. Untuk mendukung kesatuan makna, aspek kebahasaan yang dimanfaatkan di dalam karikatur adalah jenis tindak tutur komisif, direktif, asertif, dan performatif. Berdasarkan cara penyampaiannya data karikatur dalam penelitian ini, ada jenis tindak tutur langsung tidak literal, tindak tutur langsung literal dan tindak tutur tidak langsung literal.

\section{DAFTAR PUSTAKA}

Geoffrey, L. (1983). Prinsip-prinsip pragmatik (diterjemahkan oleh M.D.D Oka). Jakarta: Balai Pustaka.

Jacob, Mey. 1993. Pragmatics: an introduction (Edisi Kedua). Oxford: Blackwell.

Kridalaksana, H. (2001). Kamus linguistik. Jakarta: Gramedia.

Lexy. M. (1990). Metodologi Penelitian kualitatif. Bandung: Rosidakarya.

Noerhadi, T.H. (1989). "Kartun dan karikatur sebagai wahana kritik sosial". Majalah Ilmu-Ilmu Sosial, XVI No.2, hal: 129-155.

Rahardi, K. (2000). Imperatif dalam bahasa Indonesia. Yogyakarta: Duta Wacana University Press.

Rahardi, K. (2003). Berkenalan dengan Ilmu bahasa pragmatik. Malang: Dioma.

Rahardi, K. (2005). Pragmatik kesantuanan imperatif dalam bahasa Indonesia. Jakarta: Erlangga.

Rohmadi, M. (2004). Pragmatik teori dan analisis. Yogyakarta: Lingkar Medeka.

Rohmadi, M. (2006). Wacana humor: analisis tekstual dan kontekstual. Yogyakarta: Proposal Disertasi Pascasarjana S3. Universitas Gadjah Mada.

Searle, J.R. (1969). Speech acts. London: Cambriedge University Press.

Sibarani, A. (2001). Karikatur dan politik. Jakarta: Gerba Budaya.

Sudarta, G.M. (1980). Indonesia 19671980. Jakarta: Gramedia. 
Supriyadi, S. (2011). Wacana karikatur indonesia perspektif kajian pragmatik. Surakarta: UNS Press.

Suwito. (1983). Pengantar awal sosiolinguistik teori dan problema. Surakarta: Henry Offset.

Wijana, I.D.P. (1985). Bahasa Indonesia dalam cerita humor. Linguistik Indonesia Vol. 5 Tahun 3.

Wijana, I.D.P. (1995). Wacana kartun dalam bahasa Indonesia. Disertasi Doktor. Yogyakarta, Universitas Gadjah Mada.

Wijana, I.D.P. (1996). Dasar-dasar pragmatik. Yogyakarta: Andi Offset.

Wijana, I.D.P. (2004). Kartun: studi tentang permainan bahasa. Yogyakarta: Ombak.

Yule, G. (2006). Pragmatik. Yogyakarta: Pustaka Pelajar. 